\title{
Frequent acquisition of simian foamy viruses from gorillas, chimpanzees and monkeys through severe bites in central African hunters with no evidence for intra-familial dissemination
}

\author{
Edouard Betsem ${ }^{1,2^{*}}$, Tortevoye Patricia ${ }^{1}$, Froment Alain ${ }^{3}$, Antoine Gessain ${ }^{1}$ \\ From 15th International Conference on Human Retroviruses: HTLV and Related Viruses \\ Leuven and Gembloux, Belgium. 5-8 June 2011
}

\section{Background}

Human infection by Simian Foamy Virus (SFV) can be acquired mainly through bites in persons occupationally exposed to non-human primates (NHP) or in natural settings.

This study aimed at getting better knowledge on the risk factors associated to presence of SFV infection in humans at risk for such zoonosis and, searching for intra-familial dissemination from the original infected cases.

\section{Results}

We studied 1257 people from the general adult population (mean age 53 yrs, women 600 and men 657) and 182 individuals, mostly men, who all encountered a NHP with a resulting bite or scratch. All of these, either Baka Pygmies (380) or Bantou (1020) people live in villages in South Cameroon, a rainforest natural habitat for several NHP species. A specific SFV Western blot was used for plasma and two nested PCR (integrase and LTR) were done on all the positive/borderline samples by serology. In the general population, 2/1257 persons were found SFV infected, one by a gorilla and one by a monkey FV. In the second group, 35/182 (19.2\%) persons were SFV positive. They were mostly infected (31/ 35 ) by apes FV (mainly gorilla), while infection by monkey FV was less frequent (3/35). Of the 30 wives and 17 children from families of FV positive persons, only one plasma, from a wife was WB positive.

\footnotetext{
* Correspondence: edouard.betsem@pasteur.fr

${ }^{1}$ EPVO unit, Department of Virology, Institut Pasteur, Paris, France
}

Full list of author information is available at the end of the article

\section{Conclusion}

We demonstrate a high level of transmission of SFVs into humans in natural settings specifically following severe apes and monkey bites and a viral persistence over several years. Secondary transmissions remain in question.

\section{Author details}

${ }^{1}$ EPVO unit, Department of Virology, Institut Pasteur, Paris, France. ${ }^{2}$ Faculté de Médecine et des Sciences Biomédicales, Université de Yaoundé 1, Cameroun. ${ }^{3} \mathrm{RD}$, Musée de l'Homme, Paris, France.

Published: 6 June 2011

doi:10.1186/1742-4690-8-S1-A237

Cite this article as: Betsem et al:: Frequent acquisition of simian foamy viruses from gorillas, chimpanzees and monkeys through severe bites in central African hunters with no evidence for intra-familial dissemination. Retrovirology 2011 8(Suppl 1):A237.

Submit your next manuscript to BioMed Central and take full advantage of:

- Convenient online submission

- Thorough peer review

- No space constraints or color figure charges

- Immediate publication on acceptance

- Inclusion in PubMed, CAS, Scopus and Google Scholar

- Research which is freely available for redistribution 